\title{
ASSESSING URBAN MOBILITY SUSTAINABILITY THROUGH A SYSTEM OF INDICATORS: THE CASE OF GREEK CITIES
}

\author{
ALEXANDROS SDOUKOPOULOS \& MAGDA PITSIAVA-LATINOPOULOU \\ Transport Engineering Laboratory, Civil Engineering Department, Aristotle University of Thessaloniki, Greece
}

\begin{abstract}
The World Commission on Environment and Development in 1987, although not the first policy document related to sustainability, led to the development of the most widely accepted definition of sustainable development. Nowadays, almost three decades later and despite the great amount of relevant research that was conducted, many cities in the world still present poor conditions in terms of sustainability and face intense environmental, economic and social problems. According to studies, a great percentage of the abovementioned problems either derive directly, or are highly associated with, the operation of the city's transport system: a fact that highlights the emergence of sustainable urban mobility. In this framework, the use of appropriate indicators as a methodological tool can play a key role for monitoring and assessing the mobility conditions in an urban area. Towards this direction, the main objective of the present study is to develop a system of appropriate indicators for assessing the sustainability of the current mobility conditions in the Greek urban areas. More specifically the development of this new sustainable urban mobility indicator system is based on the main findings of an extensive literature review on relevant indicator systems accordingly adjusted to the specific characteristics of the Greek urban areas.
\end{abstract}

Keywords: sustainable urban mobility indicators, overview of indicator systems.

\section{INTRODUCTION}

The prevailing development model being implemented since the last decades of 20th century, although contributed to a substantial improvement of living standards, further increased social inequalities and imbalances in consumption and production patterns, resulted at the same time in environmental deterioration [1], [2]. The increasing intensity of the abovementioned phenomena as well as their irreversible in the long-term negative effects led a great number of relevant stakeholders, including international organizations, scientific community, policy makers, etc., to revise the followed approach in development and conceptualize an alternative paradigm namely sustainable development, which integrates environmental, social and economic concerns. According to the World Commission on Environment and Development (1987), sustainable development is defined as "meeting the needs of the present without compromising the ability of future generations to meet their own needs" [3] and since 1992, when the United Nations (UN) Conference on Environment and Development demonstrated its fundamental principles, is considered as a high-priority issue on the agenda of international community [1], [2].

Sustainable planning is of major importance especially in urban areas, where many problems are accumulated [2]. Nowadays, $54 \%$ of the world population lives in cities, while a further increase up to $12 \%$ is expected to be realized till 2050 [4]. Moreover, while urban areas generate up to $40 \%$ and $80 \%$ of the national Gross Domestic Product (GDP) in developing and developed countries respectively, a significant share of urban population is suffering from deprivation at a great degree, indicating thus the existence of extreme social and economic inequalities [5]. Furthermore, most urban areas are facing serious challenges and increasing pressures regarding the environmental quality. 
Moving towards urban sustainability not only involves adoption and implementation of governmental policies and measures that aim at altering patterns in different sectors e.g. energy, waste, urban planning, transport, but also requires fundamental changes in the way each person identifies problems and considers solutions, highlighting thus the need for developing a common sense on behalf of all members of the society [2], [6]. In this framework, the incorporation of the main principles of sustainability in transport planning towards the change of individuals' transport decisions and travel behaviour in favour of sustainable modes and services constitutes a critical issue, since transport comprises a major component of every urban area. More specifically as transport system provides physical access to jobs, education, health, leisure, resources, markets and goods any deficiencies in its design and operation could result in low sustainability levels and great economic, environmental and social externalities [7]. In this context, according to recent (2014) estimations referring to European cities, congestion cost accounts for approximately $€ 100$ billion per year corresponding to $1 \%$ of the EU's GDP [8]. Moreover, urban mobility contributes significantly to $\mathrm{CO}_{2}$ and other air pollutants $\left(\mathrm{NO}_{\mathrm{x}}, \mathrm{PM}_{10}, \mathrm{SO}_{\mathrm{x}}, \mathrm{CO}, \mathrm{NMVOCs}\right)$ emissions generated from road transport sector (corresponding to approximately $40 \%$ and $70 \%$ respectively), resulting in poor air quality and a significant number of premature deaths every year [9], [10]. In addition, at least 125 million people are exposed to levels above the Environmental Noise Directive threshold of $55 \mathrm{~dB} \mathrm{~L}_{\mathrm{den}}$ due to road traffic noise [10]. Furthermore, the share of road fatalities in urban areas is quite high (38\%), while almost half of these fatalities refer to vulnerable road users such as pedestrians and cyclists [11], [12]. The afore-mentioned indicate that, despite the approximately three decades passed from the declaration of sustainability agenda and the considerable amount of relevant research conducted since then, achieving urban transport sustainability constitutes a challenging task and in many cases an ambitious ongoing goal.

The constant monitoring and evaluation of the current mobility conditions comprises a necessary process towards sustainability according to the following: an issue which is not clearly defined and measured is difficult to get managed and improved, and "we are what we measure; it's time to measure what we want to be", [13]-[15]. Towards this direction, indicators due to their specific characteristics consist one of the most suitable, comprehensive and "convenient" methodological tools, being increasingly implemented during the last years [16]. Indicators are selected, targeted, quantitative or qualitative measures designed to evaluate and illustrate progress towards defined visions, goals and objectives [17]-[19]. More specifically, sustainable transport indicators are widely described as statistical measurements that indicate the sustainability of transport system in terms of social, environmental and economic development [20]-[22]. Indicators are designed to highlight significant trends and track intense problems [17]-[19]. Moreover, indicators reflect public concerns and communicate complex phenomena in a simple manner both understandable by experts and public [17], [18]. Furthermore, indicators contribute to priority-setting constituting thus a valuable tool both for policy makers and decision-takers [23].

As far as indicators' selection criteria are concerned, sustainable transport indicators should be relevant to the vision, policies and goals that are expected to evaluate or in other words indicators should provide useful information regarding the performance of transport system in terms of economic, environmental and social sustainability [13], [20], [23]. According to several authors, indicators should enable comparisons between different phenomena, time periods, areas and jurisdictions, while at the same time they should be sensitive enough to point out even slight changes [13], [18], [19], [21], [25]. Additionally, indicators should contribute to the monitoring of the current mobility conditions to an extent that offsets the required calculation cost, which in every occasion must be feasible [13], [23], 
[25]. The necessary original data should be of high accuracy and quality, whilst data collection process should be time-efficient and cost-effective as well [23]. Furthermore, indicators have to be simple and transparent so as to be accessible and easily understandable not only by experts but also by public [23], [25]. In this regard, indicators' expressions should be brief yet clear, explicit and as close as possible to their description. For instance, the indicator "access to basic services" can potentially lead to misleading conclusions, since according to some researchers refers to the average commuting distance, while for others to the average travel time required to reach basic purposes. Moreover, it should be pointed out here that indicators' structure should facilitate the setting of reference values, either goals or thresholds, since indicators' values (e.g. "O $\mathrm{O}_{3}$ Concentration level": $110 \mu \mathrm{g} / \mathrm{m}^{3}$ ), unless being compared to a reference (e.g. "O ${ }_{3}$ Concentration threshold": $120 \mu \mathrm{g} / \mathrm{m}^{3}$ ), limit the ability to draw explicit conclusions regarding sustainability [26].

Despite the general agreement concerning the indicators' selection criteria, the literature study illustrates a great variability in the features of the developed indicator systems and indexes as well as the indicators involved. The aforementioned could be considered as the combined result of the high interest in sustainability issues, the complexity of the transport system and the different characteristics of each area [27]. Explicitly, a specific policy, goal or measure as well as the corresponding indicators that are significant and appropriate in terms of sustainability for a particular country or urban area, may be proved less suitable, unimportant and of unjustified economic and social cost for another area [2]. For instance, soil contamination due to road salting and the respective indicator "Annual use of road salt per snowy day" might be of prime importance concerning environmental sustainability in countries of North Europe or America such as Sweden, USA and Canada [16], [28], but of little importance in countries like Greece, where road salting is used to a negligible extent. On the other hand, quality of road pavements and the indicator "Number of potholes per km of road length" might be suitable for evaluating economic efficiency of transport system in developing countries like India, yet of less importance in developed countries such as United Kingdom or Germany [29]. In this context, the main objective of the present research is the development of a new sustainable urban mobility indicator system based on the main findings of an extensive literature review on relevant indicator initiatives and accordingly adjusted to the specific characteristics of the Greek urban areas.

\section{OVERVIEW OF SUSTAINABLE TRANSPORT INDICATOR SYSTEMS AND INDEXES}

The UN Agenda 21, although not the first policy document encouraging countries and organizations to develop and use sustainability indicator systems, had a major influence on international community and contributed significantly to the conduction of relevant research [1], [30]. In the framework of the current research, 70 indicator initiatives referring to systems and indexes (i.e. group of indicators aggregated into a single value) as well as 2391 indicators were examined. The selected initiatives either aim at evaluating all the pillars of sustainability (i.e. environmental, economic and social) of the transport system or focus on the environmental pillar and they were developed in the context of relevant research projects or studies conducted by international organizations, national and local authorities as well as research institutes and other research teams. It should be pointed out here, that indicator initiatives generally referring to sustainable development (e.g. energy, waste, water) were also included in the review if transport was considered as a major component. The main characteristics of the examined indicator systems and indexes are summarized and briefly presented in Table 1 and Fig. 1 respectively. 
Table 1: Main characteristics of the examined indicator initiatives.

\begin{tabular}{|c|c|c|c|c|c|c|c|c|}
\hline Authors & Year & Origin & Categ. ${ }^{1}$ & Focus & Type & Spatial level & H.L. ${ }^{2}$ & IND. ${ }^{3}$ \\
\hline US EPA [28] & 1996 & USA & $\mathrm{ST}^{4}$ & Env. ${ }^{6}$ & System $^{8}$ & National & 4 & 101 \\
\hline Kupiszewska [31] & 1997 & UK & ST & All pillars ${ }^{7}$ & System & Urban & 3 & 48 \\
\hline Lautso et al. [32] & 1998 & $\mathrm{EU}$ & ST & All pillars & System & Urban & 3 & 23 \\
\hline OECD [22] & 1999 & OECD & ST & Env. & System & National & 3 & 43 \\
\hline EEA [33] & 2000 & $\mathrm{EU}$ & ST & Env. & System & National \& EU & 3 & 47 \\
\hline ISTAT [34] & 2001 & Italy & $\mathrm{SD}^{5}$ & Env. & System & Urban & 4 & 38 \\
\hline Caratt et al. [35] & 2001 & $\mathrm{EU}$ & ST & All pillars & System & Urban & 2 & 42 \\
\hline Gilbert et al. [36] & 2002 & Canada & ST & All pillars & System & National & 2 & 14 \\
\hline Zietsman et al. [37] & 2003 & USA & ST & All pillars & Index & Road corridor & 3 & 11 \\
\hline Coplak \& Raksanyi [38] & 2003 & EU & SD & All pillars & System & Urban & 2 & 73 \\
\hline Borken [39] & 2003 & Germany & ST & Env. & System & $\begin{array}{c}\text { National \& } \\
\text { Regional }\end{array}$ & 3 & 11 \\
\hline Minken et al. [40] & 2003 & $\mathrm{EU}$ & ST & All pillars & System & Urban & 2 & 21 \\
\hline Imran \& Low [41] & 2003 & Pakistan & ST & All pillars & System & Urban & 3 & 48 \\
\hline Berrini et al. [42] & 2003 & $\mathrm{EU}$ & ST & All pillars & System & Urban & 1 & 10 \\
\hline Nicolas et al. [43] & 2003 & France & ST & All pillars & System & Urban & 3 & 32 \\
\hline Lautso et al. [44] & 2004 & $\mathrm{EU}$ & ST & All pillars & Index & Urban & 3 & 35 \\
\hline Svensson [45] & 2004 & $\mathrm{EU}$ & ST & All pillars & System & Road corridor & 4 & 14 \\
\hline WBCSD [46] & 2004 & WBCSD & ST & All pillars & System & National & 2 & 40 \\
\hline World Bank [47] & 2004 & $\begin{array}{l}\text { World } \\
\text { Bank } \\
\end{array}$ & ST & All pillars & System & National & 2 & 57 \\
\hline WHO [48] & 2004 & WHO & SD & Env. & System & National \& EU & 3 & 13 \\
\hline Costa et al. [49] & 2005 & Brazil & ST & All pillars & Index & Urban & 3 & 24 \\
\hline CAI-Asia [50] & 2005 & India & ST & All pillars & Index & Urban & 3 & 50 \\
\hline Risser et al. [51] & 2005 & EU & ST & All pillars & System & Urban & 2 & 36 \\
\hline Marsden et al. [52] & 2005 & UK & ST & All pillars & System & Urban & 4 & 75 \\
\hline Schäfer [53] & 2005 & Germany & ST & All pillars & System & Urban & 3 & 9 \\
\hline $\begin{array}{l}\text { Rahman \& van Grol } \\
\text { [54] }\end{array}$ & 2005 & $\mathrm{EU}$ & ST & All pillars & System & National & 3 & 90 \\
\hline CAI-Asia [55] & 2005 & CAI-Asia & ST & All pillars & System & Urban & 2 & 14 \\
\hline Frei [56] & 2006 & Brazil & ST & All pillars & Index & Urban & 1 & 8 \\
\hline Litman \& Burwell [57] & 2006 & $\begin{array}{l}\text { Canada \& } \\
\text { USA }\end{array}$ & ST & All pillars & System & Urban & 3 & 23 \\
\hline Savelson et al. [58] & 2006 & Canada & ST & All pillars & System & $\begin{array}{c}\text { National \& } \\
\text { Regional } \\
\end{array}$ & 3 & 31 \\
\hline Taylor [59] & 2006 & $\mathrm{EU}$ & ST & All pillars & System & Urban & 1 & 44 \\
\hline $\begin{array}{l}\text { Dobranskyte-Niskota et } \\
\text { al. [23] }\end{array}$ & 2007 & EU & ST & All pillars & Index & National \& EU & 3 & 57 \\
\hline Appleton et al. [60] & 2007 & Canada & ST & All pillars & Index & Urban & 2 & 17 \\
\hline Sessa et al. [61] & 2007 & $\mathrm{EU}$ & ST & All pillars & System & National \& EU & 3 & 93 \\
\hline Häkkinen [62] & 2007 & EU & SD & All pillars & System & Urban & 2 & 32 \\
\hline Pai [63] & 2007 & India & ST & All pillars & System & Urban & 1 & 19 \\
\hline $\begin{array}{l}\text { Maoh \& Kanaroglou } \\
\text { [64], [65] }\end{array}$ & 2008 & Canada & ST & All pillars & Index & Urban & 3 & 21 \\
\hline
\end{tabular}


Table 1: Continued.

\begin{tabular}{|c|c|c|c|c|c|c|c|c|}
\hline Authors & Year & Origin & Categ. ${ }^{1}$ & Focus & Type & Spatial level & H.L. ${ }^{2}$ & $\mathrm{IND}^{3}$ \\
\hline Costa [66], [67] & 2008 & Brazil & ST & All pillars & Index & Urban & 4 & 87 \\
\hline Campos et al. [68] & 2008 & Brazil & ST & All pillars & Index & Urban & 3 & 26 \\
\hline Litman [69] & 2008 & Canada & ST & All pillars & System & Urban & 3 & 30 \\
\hline Ramani et al. [70] & 2009 & USA & ST & All pillars & Index & Road corridor & 3 & 13 \\
\hline Litman [19] & 2009 & Canada & ST & All pillars & System & National & 2 & 41 \\
\hline Yigitcanlar \& Dur [71] & 2010 & Australia & ST & All pillars & Index & Urban & 3 & 30 \\
\hline $\begin{array}{l}\text { Joumard \& } \\
\text { Gudmundsson [20] }\end{array}$ & 2010 & $\mathrm{EU}$ & ST & Env. & System & National & 4 & 49 \\
\hline Castillo \& Pitfield [72] & 2010 & UK & ST & All pillars & System & Urban & 1 & 15 \\
\hline $\begin{array}{l}\text { Moussiopoulos et al. } \\
\text { [73] }\end{array}$ & 2010 & Greece & SD & All pillars & System & Urban & 2 & 46 \\
\hline Jeon et al. [74], [75] & 2010 & USA & ST & All pillars & Index & Urban & 3 & 30 \\
\hline $\begin{array}{l}\text { Gunyoung \& Sangyong } \\
{[76]}\end{array}$ & 2011 & $\begin{array}{l}\text { South } \\
\text { Korea } \\
\end{array}$ & ST & All pillars & Index & National & 2 & 9 \\
\hline Zito \& Salvo [77] & 2011 & Italy & ST & All pillars & Index & Urban & 2 & 24 \\
\hline $\begin{array}{l}\text { Awasthi \& Chauhan } \\
\text { [78] }\end{array}$ & 2011 & Canada & ST & All pillars & Index & Urban & 2 & 9 \\
\hline $\begin{array}{l}\text { UNCRD \& CAI-Asia } \\
\text { [79] }\end{array}$ & 2011 & CAI-Asia & ST & All pillars & System & National & 2 & 84 \\
\hline Litman [80] & 2011 & Canada & ST & All pillars & System & Urban & 2 & 44 \\
\hline US EPA [81] & 2011 & USA & ST & All pillars & System & $\begin{array}{l}\text { Urban \& } \\
\text { Regional } \\
\end{array}$ & 1 & 17 \\
\hline Toth-Szabo et al. [16] & 2011 & Sweden & $\mathrm{ST}$ & All pillars & System & Urban & 3 & 89 \\
\hline Nathan \& Reddy [29] & 2011 & India & ST & All pillars & System & Urban & 2 & 58 \\
\hline $\begin{array}{l}\text { Haghshenas \& Vaziri } \\
{[21],[82]}\end{array}$ & 2012 & Iran & ST & All pillars & Index & Urban & 3 & 9 \\
\hline Nenseth et al. [83] & 2012 & Norway & ST & All pillars & System & Urban & 3 & 43 \\
\hline Shiau \& Liu [84] & 2013 & Taiwan & ST & All pillars & Index & $\begin{array}{l}\text { Urban \& } \\
\text { Regional }\end{array}$ & 3 & 21 \\
\hline $\begin{array}{l}\text { EcoMobility SHIFT } \\
\text { [85] }\end{array}$ & 2013 & $\mathrm{EU}$ & ST & All pillars & Index & Urban & 2 & 23 \\
\hline Zheng et al. [13] & 2013 & USA & ST & All pillars & Index & $\begin{array}{c}\text { National \& } \\
\text { Regional }\end{array}$ & 4 & 22 \\
\hline $\begin{array}{l}\text { van Rooijen \& } \\
\text { Nesterova [86] }\end{array}$ & 2013 & EU & ST & All pillars & System & Urban & 4 & 32 \\
\hline Santos \& Ribeiro [87] & 2013 & Brazil & ST & All pillars & System & Urban & 2 & 20 \\
\hline Litman [88] & 2013 & Canada & ST & All pillars & System & Urban & 4 & 41 \\
\hline Reisi et al. [89] & 2014 & Australia & ST & All pillars & Index & Urban & 2 & 9 \\
\hline Mameli \& Marletto [90] & 2014 & Italy & ST & All pillars & System & Urban & 2 & 13 \\
\hline $\begin{array}{l}\text { Pitsiava-Latinopoulou } \\
\text { [91] }\end{array}$ & 2014 & Greece & ST & All pillars & System & Urban & 2 & 30 \\
\hline Moeinaddini et al. [92] & 2015 & Malaysia & ST & All pillars & Index & Urban & 1 & 19 \\
\hline Alonso et al. [93] & 2015 & Spain & ST & All pillars & Index & Urban & 2 & 9 \\
\hline Shiau et al. [94] & 2015 & Taiwan & ST & All pillars & Index & National & 2 & 19 \\
\hline Verma et al. [95] & 2015 & India & ST & All pillars & Index & Urban & 3 & 16 \\
\hline \multicolumn{9}{|c|}{$\begin{array}{l}\text { Abbreviations: Categ. }{ }^{1}: \text { Category; H.L. }{ }^{2}: \text { Number of hierarchical levels considered (from sustainability pillars to } \\
\text { indicators); Ind. }{ }^{3}: \text { Number of indicators included; } T^{4}: \text { Sustainable transport; SD } D^{5}: \text { Sustainable development; Env. }{ }^{6}: \text { Only } \\
\text { environment is considered; All pillars }{ }^{7}: \text { All sustainability pillars are considered; System }{ }^{8}: \text { Indicator system. }\end{array}$} \\
\hline
\end{tabular}



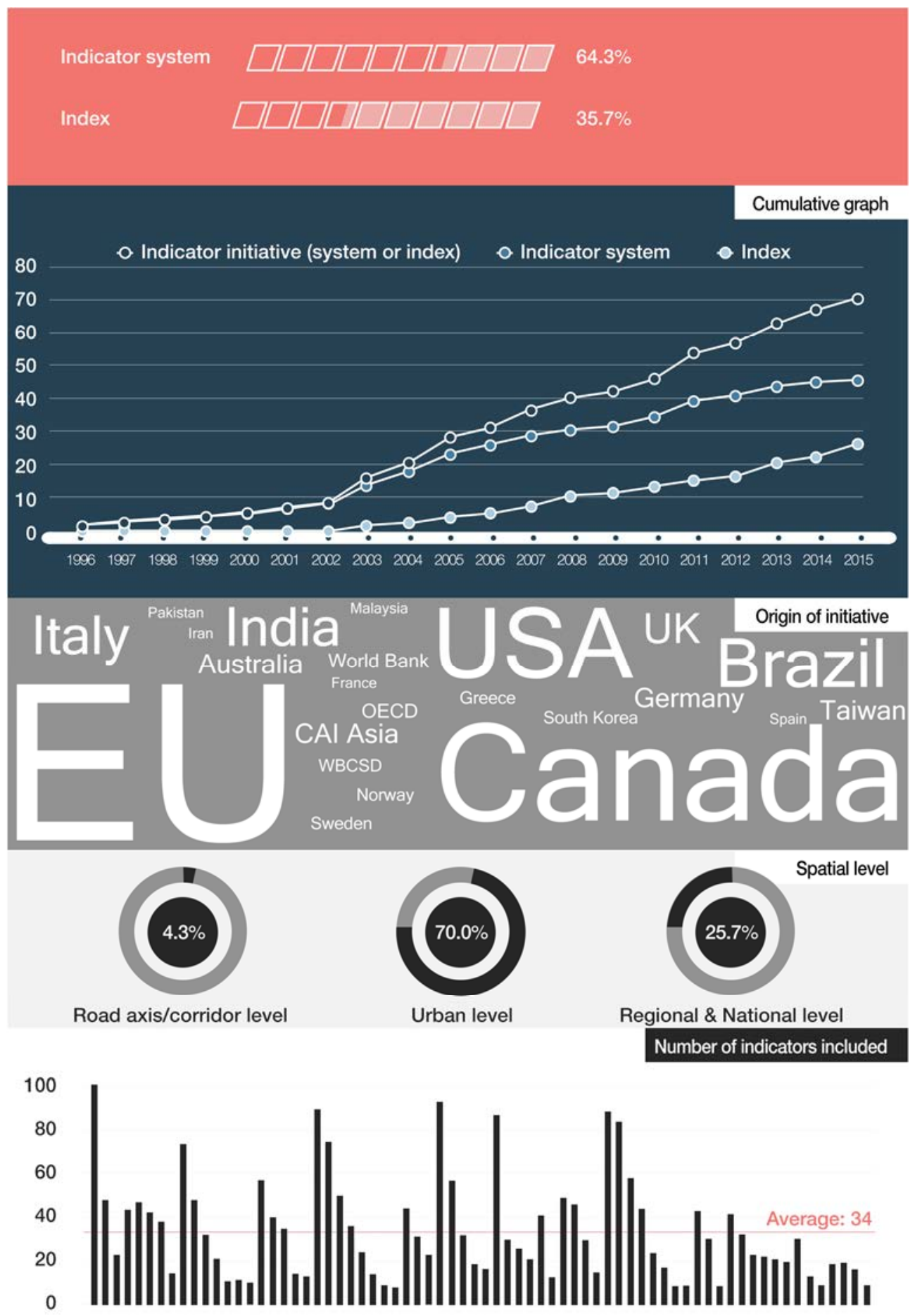

Figure 1: Visualization of the main characteristics of the examined indicator initiatives. 
According to the Fig. 1, the majority of the examined initiatives (64.3\%) refer to indicator systems, while indexes correspond to $35.7 \%$. The inclusion of aggregate indicators into an index did not constitute a widely adopted methodological approach, at least until 2002, when researchers started to develop more sophisticated sustainable transport indexes using various weighting and normalization methods. As far as the "origin" of the selected indicator initiatives is concerned, most of them have been introduced in developed countries. More specifically, 17 out of 70 indicator initiatives $(24.3 \%)$ were developed in the framework of EU-funded projects, while a considerable share (18.5\%) corresponds to initiatives conducted by national authorities or local research teams from European countries. Moreover, as indicated by the development of 9 relevant indicator initiatives, Canadian institutes such as the Victoria Transport Policy Institute promote to a great extent the research referring to sustainable transport indicators. Furthermore, 6 initiatives missing specific spatial reference were developed by international organizations or research institutes e.g. World Bank, CAIAsia, WBCSD. Additionally, 60 out of 70 indicator initiatives consider all the sustainability pillars of the transport system, while the rest 10 focus only on the environment. Regarding the spatial level of the indicators, $70 \%$ of the examined initiatives assess urban transport sustainability, whilst approximately $26 \%$ evaluate transport sustainability at regional, national or EU level. Concerning the number of hierarchical levels, i.e. the levels involved in the structure of each indicator system or index (e.g. higher level: sustainability pillars, middle level: sustainability goals, lower level: sustainability indicators), the prevailing number is 3. Finally, the number of indicators included in each initiative ranges from 8 to 101, with an average of 34 indicators, which is being exceeded in 28 out of the $70(40 \%)$ examined initiatives.

\section{DEVELOPMENT OF A NEW SUSTAINABLE TRANSPORT INDICATOR SYSTEM FOR THE GREEK URBAN AREAS}

Taking into consideration the main findings of the literature review, the EU and Greek transport-related policy documents as well as the specific characteristics of the Greek urban areas, a new sustainable transport indicator system was developed. More specifically, Greek urban areas are heavily dependent on car use resulting thus in high levels of congestion and traffic noise, while public space is often of poor quality. Moreover, most Greek urban authorities have limited abilities in data gathering due to lack of efficient and reliable data collection mechanisms and economic constraints. Furthermore, Greek cities lag considerably behind adopting new technologies and services regarding the transport system, whilst the functional and administrative boundaries in many cases such as the metropolitan areas of Athens and Thessaloniki do not coincide. Having all these in mind, the proposed indicator system consists of the principal indicators that evaluate urban transport sustainability, so that it is not data demanding and could be implemented in urban areas as well as in subareas such as the different municipalities constituting a metropolitan area. The developed indicator system is presented in Table 2 .

\section{CONCLUDING REMARKS}

Sustainable urban mobility should comprise the vision for every urban area. Towards this direction, indicators can play a vital role due to their numerous advantages. In the framework of the current research, a new sustainable transport indicator system for the Greek urban areas was developed. The proposed indicator system, based on the main findings of an extensive literature review and the specific characteristics of the Greek urban areas, constitutes a necessary step towards promoting transport sustainability in Greek cities. As far as the future 
research is concerned, the developed indicator system should be further exploited as an input for defining a sustainable transport index for the Greek urban areas.

Table 2: $\quad$ Presentation of the new sustainable transport indicator system for the Greek urban areas.

\begin{tabular}{|c|c|c|}
\hline PILLARS & THEME & INDICATOR \\
\hline \multirow{4}{*}{ 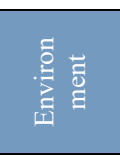 } & \multirow{5}{*}{$\begin{array}{l}\text { Air pollutant } \\
\text { emissions }\end{array}$} & Daily PM transport emissions per capita \\
\hline & & Daily $\mathrm{NO}_{\mathrm{x}}$ transport emissions per capita \\
\hline & & Daily CO transport emissions per capita \\
\hline & & Daily VOC transport emissions per capita \\
\hline \multirow{20}{*}{ 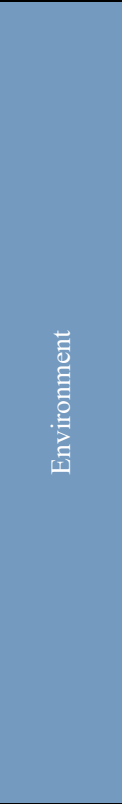 } & & Daily $\mathrm{SO}_{2}$ transport emissions per capita \\
\hline & \multirow{3}{*}{$\begin{array}{l}\text { GHG } \\
\text { emissions }\end{array}$} & Daily $\mathrm{CO}_{2}$ transport emissions per capita \\
\hline & & Daily $\mathrm{CH}_{4}$ transport emissions per capita \\
\hline & & Daily $\mathrm{N}_{2} \mathrm{O}$ transport emissions per capita \\
\hline & \multirow{4}{*}{ Air quality } & Number of days per year in which CO concentrations exceed $10 \mu \mathrm{g} / \mathrm{m}^{3}$ \\
\hline & & Number of hours per year in which $\mathrm{NO}_{2}$ concentrations exceed $200 \mu \mathrm{g} / \mathrm{m}^{3}$ \\
\hline & & Number of days per year in which $\mathrm{O}_{3}$ concentrations exceed $120 \mu \mathrm{g} / \mathrm{m}^{3}$ \\
\hline & & Number of days per year in which $\mathrm{PM}_{10}$ concentrations exceed $50 \mu \mathrm{g} / \mathrm{m}^{3}$ \\
\hline & Traffic noise & Traffic noise levels along main road axis \\
\hline & \multirow{5}{*}{$\begin{array}{l}\text { Liveable } \\
\text { public space } \\
\text { and amenities }\end{array}$} & $\begin{array}{l}\text { Share of sidewalks and footpaths in the central area occupied by illegal parked } \\
\text { vehicles }\end{array}$ \\
\hline & & $\begin{array}{l}\text { Level of residents' satisfaction regarding the aesthetics and cleanliness of the public } \\
\text { space }\end{array}$ \\
\hline & & Land taken by motorised transport infrastructure as a share of the public space \\
\hline & & Total area of squares and footpaths per capita \\
\hline & & Area of public green spaces per capita \\
\hline & Multimodality & $\begin{array}{l}\text { Share of metro/tram stations and main bus stops with facilities that promote } \\
\text { multimodality }\end{array}$ \\
\hline & \multirow{4}{*}{$\begin{array}{l}\text { Renewables } \\
\text { and } \\
\text { alternative } \\
\text { fuels }\end{array}$} & Number of charging facilities for electric vehicles per 1,000 residents \\
\hline & & Share of fuel stations selling alternative fuels \\
\hline & & Share of municipal vehicle fleet using alternative fuels \\
\hline & & Share of PT passenger-km travelled by alternatively-fuelled vehicles \\
\hline & Water run-off & Impervious surface as a share of the total land taken by transport infrastructure \\
\hline \multirow{9}{*}{ 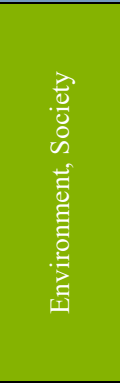 } & Fragmentation & $\begin{array}{l}\text { Ratio of the largest continuous area (not fragmented by major transport } \\
\text { infrastructure) to the total area }\end{array}$ \\
\hline & \multirow{8}{*}{$\begin{array}{l}\text { Non- } \\
\text { motorised } \\
\text { modes }\end{array}$} & Bicycle routes as a share of the total road network length \\
\hline & & \begin{tabular}{|l|} 
Footpaths as a share of the total road network length \\
\end{tabular} \\
\hline & & $\begin{array}{l}\text { Traffic calmed roads as well as streets with } 30 \mathrm{~km} / \mathrm{h} \text { speed limit as a share of the } \\
\text { total road network length }\end{array}$ \\
\hline & & Number of bike-sharing stations per 1,000 residents \\
\hline & & Number of bicycle parking spaces per 1,000 residents \\
\hline & & Share of traffic lights with pedestrian red phase longer than $\mathrm{x} \mathrm{sec}$ \\
\hline & & Length-weighted average walkability score of the sidewalks in the central area \\
\hline & & Length-weighted average cyclability score of the bicycle routes in the central area \\
\hline \multirow{9}{*}{$\begin{array}{l}3 \\
\frac{\pi}{0} \\
0 \\
0 \\
\text { in }\end{array}$} & \multirow{7}{*}{$\begin{array}{l}\text { Public } \\
\text { transport }\end{array}$} & Average household distance to closest PT stop/station \\
\hline & & \begin{tabular}{|l|} 
Share of PT stops/stations with adequate passenger comfort amenities \\
\end{tabular} \\
\hline & & Information availability at PT stops/stations and on PT vehicles \\
\hline & & \begin{tabular}{|l|} 
Ratio of PT trips served to PT trips scheduled \\
\end{tabular} \\
\hline & & Average coefficient of variation of headways \\
\hline & & Average PT frequency \\
\hline & & Ratio of average PT speed to average private car speed \\
\hline & \multirow{2}{*}{ Accessibility } & Share of residents with access to basic services by walking or PT \\
\hline & & Share of street corners with installed kerb ramps \\
\hline
\end{tabular}


Table 2: Continued.

\begin{tabular}{|c|c|c|}
\hline $2-1$ & THEME & INDICATOR \\
\hline \multirow{16}{*}{$\begin{array}{l}\frac{3}{0} \\
\frac{0}{3} \\
\text { क }\end{array}$} & & $\begin{array}{l}\text { Share of sidewalks and footpaths with installed tactile paving strips to facilitate } \\
\text { movements of vision-impaired people }\end{array}$ \\
\hline & & $\begin{array}{l}\text { Share of signalised intersections with installed audible devices to facilitate movements of } \\
\text { vision-impaired people }\end{array}$ \\
\hline & Affordability & Share of household income devoted to transport \\
\hline & \multirow{4}{*}{$\begin{array}{l}\text { Active } \\
\text { citizens }\end{array}$} & $\begin{array}{l}\text { Number of stakeholders finally attending transport-related decision-making process to } \\
\text { the total number of stakeholders initially called to participate }\end{array}$ \\
\hline & & $\begin{array}{l}\text { Number of citizens' associations \& NGO's dealing with transport-related issues in the } \\
\text { study area per } 1,000 \text { residents }\end{array}$ \\
\hline & & $\begin{array}{l}\text { Degree to which social networks are involved to facilitate citizens' participation in } \\
\text { transport planning process }\end{array}$ \\
\hline & & $\begin{array}{l}\text { Degree to which residents are willing to reduce the number of their daily car trips in } \\
\text { favour of alternative modes of transport }\end{array}$ \\
\hline & \multirow{5}{*}{ Safety } & Annual number of road traffic fatalities per 1,000 passenger-km \\
\hline & & Annual number of road traffic injuries per 1,000 passenger-km \\
\hline & & Annual number of road traffic accidents with vulnerable users per 1,000 passenger-km \\
\hline & & Share of school zones with implemented road safety measures \\
\hline & & $\begin{array}{l}\text { Share of road network length where the average daily running speed exceeds the } \\
\text { respective speed limit }\end{array}$ \\
\hline & \multirow{4}{*}{ Security } & Ratio of street lighting intensity to the area of public space \\
\hline & & $\begin{array}{l}\text { Ratio of annual number of recorded incidents against PT passengers to annual passenger- } \\
\mathrm{km} \text { travelled by PT }\end{array}$ \\
\hline & & Annual number of recorded vehicles (private cars and trucks) thefts per 1,000 residents \\
\hline & & Perceived level of security \\
\hline \multirow{7}{*}{$\begin{array}{l}\overline{0} \\
0 \\
0 \\
8 \\
1 \\
\frac{1}{0} \\
\frac{0}{0} \\
0 \\
0\end{array}$} & \multirow{4}{*}{ Mobility } & $\begin{array}{l}\text { Percentage change in road network capacity in the central area due to illegal parking } \\
\text { during peak periods }\end{array}$ \\
\hline & & Share of road network length with high level of congestion (in $\mathrm{km} * \mathrm{~h}$ ) \\
\hline & & Share of trips from/to school made by private car \\
\hline & & Share of trips for shopping and personal business made by private car \\
\hline & \multirow{3}{*}{$\begin{array}{l}\text { Urban } \\
\text { planning and } \\
\text { land-uses }\end{array}$} & Land-use mix \\
\hline & & Population density \\
\hline & & Employment density \\
\hline \multirow{10}{*}{ 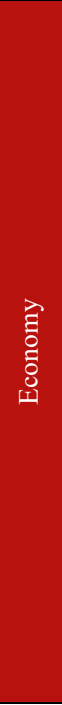 } & $\begin{array}{l}\text { Economic } \\
\text { productivity }\end{array}$ & $\begin{array}{l}\text { Share of local authority's revenues from operation and enforcement of parking system, } \\
\text { devoted to projects that promote sustainable mobility }\end{array}$ \\
\hline & $\begin{array}{l}\text { Public } \\
\text { expenditures } \\
\& \text { investments } \\
\text { in transport } \\
\text { system } \\
\end{array}$ & Share of local authority's financing devoted to transport \\
\hline & $\begin{array}{l}\text { Demographic } \\
\text { and socio- } \\
\text { economic } \\
\text { characteristics }\end{array}$ & $\begin{array}{l}\text { Number of employees living and working in the study area to the number of employees } \\
\text { living in the study area }\end{array}$ \\
\hline & \multirow{2}{*}{$\begin{array}{l}\text { Urban freight } \\
\text { transport }\end{array}$} & $\begin{array}{l}\text { Percentage change in road network capacity in the central area due to illegal parked } \\
\text { trucks during peak periods }\end{array}$ \\
\hline & & $\begin{array}{l}\text { Degree to which issues related to urban freight transport are included in SUMP and } \\
\text { existence or not of a Sustainable Urban Logistics Plan }\end{array}$ \\
\hline & \multirow{2}{*}{$\begin{array}{l}\text { New \& smart } \\
\text { technologies }\end{array}$} & $\begin{array}{l}\text { Number of e-government services provided by the public domain as well as the local } \\
\text { authority }\end{array}$ \\
\hline & & Number of transport-related iOS \& Android applications referring to the study area \\
\hline & \multirow{3}{*}{$\begin{array}{l}\text { Institutional } \\
\text { aspects }\end{array}$} & Number of institutional stakeholders involved in transport planning process \\
\hline & & Percentage of SUMP completion \\
\hline & & $\begin{array}{l}\text { Number of implemented projects and studies that promote sustainable mobility during } \\
\text { the last five years per } 1,000 \text { residents }\end{array}$ \\
\hline
\end{tabular}


Table 2: Continued.

\begin{tabular}{|c|c|c|}
\hline & THEME & INDICATOR \\
\hline \multirow{8}{*}{ 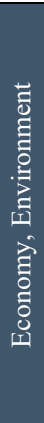 } & \multirow{2}{*}{$\begin{array}{l}\text { Transport } \\
\text { efficiency }\end{array}$} & Average occupancy rate of private cars \\
\hline & & Average occupancy rate of $\mathrm{PT}$ \\
\hline & \multirow{2}{*}{$\begin{array}{l}\text { Energy } \\
\text { efficiency }\end{array}$} & $\begin{array}{l}\text { Energy efficiency of municipal vehicle fleet defined as the ratio of vehicle-km to the } \\
\text { respective energy consumption }\end{array}$ \\
\hline & & Energy efficiency of street lighting \\
\hline & \multirow{4}{*}{ Parking } & $\begin{array}{l}\text { On-street parking in the central area as a share of the total number of parking spaces in the } \\
\text { central area }\end{array}$ \\
\hline & & $\begin{array}{l}\text { Capacity of off-street parking stations in the central area as a share of the total capacity of } \\
\text { off-street parking stations both at the central and its adjacent area }\end{array}$ \\
\hline & & $\begin{array}{l}\text { Illegal on-street parking in the central area as a share of the total number of parked vehicles } \\
\text { in the central area }\end{array}$ \\
\hline & & $\begin{array}{l}\text { Average cost of short-term }(2 \mathrm{~h}) \text { parking in off-street stations as a share of the respective } \\
\text { cost of long-term }(8 \mathrm{~h}) \text { parking }\end{array}$ \\
\hline
\end{tabular}

\section{ACKNOWLEDGEMENT}

The current paper is based on the research conducted in the framework of the project entitled "Development of a comprehensive methodology for assessing urban mobility sustainability towards mobility management", being funded by the programme "RESEARCH PROJECTS FOR EXCELLENCE IKY/SIEMENS”.

\section{REFERENCES}

[1] United Nations, Report of the World Commission on Environment and Development, Agenda 21: Programme of Action for Sustainable Development - Rio Declaration, United Nations Publication, 1992.

[2] United Nations, Report of the World Summit on Sustainable Development, United Nations Publication, 2002.

[3] United Nations, Report of the World Commission on Environment and Development, United Nations Publication, 1987.

[4] United Nations, World urbanization prospects: The 2014 Revision, UN Department of Economic and Social Affairs, Population Division, 2015.

[5] United Nations-Habitat, the state of the world's cities report 2006/2007: 30 Years of Shaping the Habitat Agenda, Earthscan: London, 2006.

[6] Litman, T.A., Reinventing Transportation - Exploring the Paradigm Shift Needed to Reconcile Transportation and Sustainability Objectives, Victoria Transport Policy Institute, 2003.

[7] World Bank, Sustainable Transport - Priorities for Policy Reform, World Bank: Washington DC, 1996.

[8] Civitas Initiative, Innovative urban transport solutions: Civitas makes the difference, Results' publication, 2014.

[9] European Commission (EC), Green paper: Towards a new culture for urban mobility, COM (2007) 551 final, European Union, Brussels, 2007.

[10] European Environmental Agency (EEA), Evaluating 15 years of transport and environmental policy integration - TERM 2015: Transport indicators tracking progress towards environmental targets in Europe. EEA Report, (7), Office for Official Publications of the European Communities: Luxembourg, 2015.

[11] European Commission (EC), Together towards competitive and resource-efficient urban mobility, COM (2013) 913 final, European Union, Brussels, 2013.

[12] European Commission (EC), Traffic Safety Basic Facts on Main Figures, European Commission, Directorate General for Transport, 2016. 
[13] Zheng, J., Garrick, N.W., Atkinson-Palombo, C., McCahill, C. \& Marshall, W., Guidelines on developing performance metrics for evaluating transportation sustainability. Research in Transportation Business \& Management, 7, pp. 4-13, 2013.

[14] Böhringer, C. \& Jochem, P.E.P., Measuring the immeasurable - A survey of sustainability indices. Ecological Economics, 63, pp. 1-8, 2007.

[15] Sustainable Measures, Online. http://sustainablemeasures.com/.

[16] Toth-Szabo, Z., Várhelyi, A., Koglin, T. \& Angjelevska, B., Measuring sustainability of transport in the city - Development of an indicator-set. Bulletin 261, Traffic \& Roads, Department of Technology and Society, Lund University, Lund, 2011.

[17] European Environmental Agency (EEA), EEA core set of indicators - Guide, EEA Technical Report, (1), Office for Official Publications of the European Communities: Luxembourg, 2005.

[18] Gilbert, R. \& Tanguay, H., Brief Review of Some Relevant Worldwide Activity and Development of an Initial Long List of Indicators. Sustainable Transportation Performance Indicators Project, The Centre for Sustainable Transportation, 2000.

[19] Litman, T.A., Sustainable transportation indicator data quality and availability, Victoria Transport Policy Institute, 2009.

[20] Joumard, R. \& Gudmundsson, H., (eds.), Indicators of Environmental Sustainability in Transport - An interdisciplinary approach to methods. Les collections de l'INRETS, 2010.

[21] Haghshenas, H. \& Vaziri, M., Urban sustainable transportation indicators for global comparison. Ecological Indicators, 15, pp. 115-121, 2012.

[22] Organisation for Economic Co-operation and Development (OECD), Indicators for the Integration of Environmental Concerns into Transport Policies, OECD Environment Policy Committee, Working Group on the State of the Environment, 1999.

[23] Dobranskyte-Niskota, A., Perujo, A. \& Pregl, M., Indicators to assess sustainability of transport activities Part 1: Review of the Existing Transport Sustainability Indicators Initiatives and Development of an Indicator Set to Assess Transport Sustainability Performance, European Commission, Joint Research Centre, 2007.

[24] Miller, H.J., Witlox, F. \& Tribby, C.P., Developing context-sensitive livability indicators for transportation planning: a measurement framework. Journal of Transport Geography, 26, pp. 51-64, 2013.

[25] Litman, T.A., Sustainable transportation indicators - A recommended research program for developing sustainable transportation indicators and data, Sustainable transportation indicators subcommittee of the Transportation Research Board, 2008.

[26] Lancker, E. \& Nijkamp, P., A policy scenario analysis of sustainable agricultural development options: a case study for Nepal. Impact Assessment and Project Appraisal, 18(2), pp. 111-124, 2000.

[27] Tafidis, P., Sdoukopoulos, A. \& Pitsiava-Latinopoulou, M., Sustainable urban mobility indicators: policy versus practice in the case of Greek cities. Proceedings of the Third Conference on Sustainable Urban Mobility, pp. 340-347, 2016.

[28] United States Environmental Protection Agency (USEPA), Indicators of the Environmental Impacts of Transportation - Highway, Rail, Aviation, and Maritime Transport, USEPA Office of Policy, Planning and Evaluation, 1996.

[29] Nathan, H.S.K. \& Reddy, B.S., Urban transport sustainability indicators Application of Multi-view Black-box (MVBB) framework, Indira Gandhi Institute of Development Research, 2011. 
[30] Bell, S. \& Morse, S., Sustainability Indicators - Measuring the immeasurable? 2, Earthscan: London and Sterling VA, 2008.

[31] Kupiszewska, D., Modelling for Sustainable Cities: The Transport Sector, Institute of Transport Studies, University of Leeds, Working Paper 521, 1997.

[32] Lautso, K., Devereux, L., Gomez, F., Martino, A. \& Wegener, M., System for planning and research in towns and cities for urban sustainability, SPARTACUS project, final report, 1998.

[33] European Environmental Agency (EEA), Are we moving in the right direction? TERM 2000: Indicators on transport and environment integration in the EU, EEA Environmental issues series, (12), Copenhagen, 2000.

[34] National Statistical Institute of Italy (ISTAT), Environmental sustainability indicators in urban areas: An Italian experience, Working Paper No. 16, Statistical Commission and Economic Commission for Europe, 2001.

[35] Caratti, P., Pinelli, D., Tarzia, V. \& Mattei, F.E.E., Sustainable urban transportation - Sustainability indicators, SUTRA D08/A First interim report, 2001.

[36] Gilbert, R., Irwin, N., Hollingworth, B. \& Blais, P., Report on Phase 3. Sustainable Transportation Performance Indicators Project, The Centre for Sustainable Transportation, 2002.

[37] Zietsman, J., Rilett, L.R. \& Kim, S.J., Sustainable transportation performance measures for developing communities, (167128), Texas Transportation Institute, The Texas A\&M University System, 2003.

[38] Coplak, J. \& Raksanyi, P., (eds), Planning sustainable settlements - Handbook based on the partial results of the EC research project ECOCITY, Slovak University of Technology Bratislava, 2003.

[39] Borken, J., Indicators for sustainable mobility - a policy oriented approach. Proceedings of the $1^{\text {st }}$ symposium on Transport \& Environment, 2003.

[40] Minken, H. et al., Developing Sustainable Land use and Transport Strategies - A Methodological Guidebook, Deliverable 14 of PROSPECTS, Institute of Transport Economics: Oslo, 2003.

[41] Imran, M. \& Low, N., Time to change the old paradigm: Promoting sustainable urban transport in Lahore, Pakistan. World Transport Policy \& Practice, 9(2), pp. 32-39, 2003.

[42] Berrini, M., Bono, L., Ferrari, G., Tarzia, V. \& Merola, M., European common indicators - Towards a local sustainability profile, Final project report, Ambiente Italia, 2003.

[43] Nicolas, J.P., Pochet, P. \& Poimboeuf, H., Towards sustainable mobility indicators: application to the Lyons conurbation. Transport Policy, 10, pp. 197-208, 2003.

[44] Lautso, K. et al., Planning and Research of Policies for Land Use and Transport for Increasing Urban Sustainability, Final Report of PROPOLIS, 2004.

[45] Svensson, A., (ed.), Arterial streets for people - Guidance for planners and decision makers when reconstructing arterial streets, ARTISTS project, 2004.

[46] World Business Council for Sustainable Development (WBCSD), Mobility 2030: Meeting the challenges to sustainability, WBCSD, The Sustainable Mobility Project, Full Report, 2004.

[47] World Bank, Performance and impact indicators for transport, World Bank Transport Indicators, 2014.

[48] World Health Organization (WHO), Environmental health indicators for Europe - A pilot indicator-based report, WHO Regional Office for Europe, 2004. 
[49] Costa, M.S., Silva, A.N.R. \& Ramos, R.A.R., Sustainable urban mobility: a comparative study and the basis for a management system in Brazil and Portugal. WIT Transactions on The Built Environment, 77, WIT Press: Southampton and Boston, pp. 323-332, 2005.

[50] Clean Air Initiative for Asian Cities (CAI-Asia), Sustainable urban transport for Pune Metropolitan area - Final Report, Partnership for Sustainable Urban Transport in Asia, 2005.

[51] Risser, R., Forward, S., Steg, L., Martincigh, L. \& Schmeidler, K., Public report on the results and products of ASI-Deliverable D13, public paper W9, Factum OHG, Swedish National Road and Transport Research Institute, 2005.

[52] Marsden, G., Kelly, C., Snell, C. \& Forrester, J., Deliverable C1 - Sustainable transport indicators: Selection and use. DISTILLATE project - Improved indicators for sustainable transport and planning, University of Leeds, University of York, 2005.

[53] Schafer, K.H., Quality targets and indicators for sustainable mobility - User guide, Umweltbundesamt: Dessau, 2005.

[54] Rahman, A. \& van Grol, R., Sustainable mobility, policy measures and assessment Final Publishable Report Version 2.0, European Commission - Directorate General for Energy and Transport, 2005.

[55] CAI-Asia, Sustainable urban transport in Asia - Making the vision a reality, Main report, CAI-Asia program, 2005.

[56] Frei, F., Sampling mobility index: Case study in Assis - Brazil. Transportation Research Part A, 40, pp. 792-799, 2006.

[57] Litman, T.A. \& Burwell, D., Issues in sustainable transportation. International Journal of Global Environmental Issues, 6(4), pp. 331-347, 2006.

[58] Savelson, A., Colman, R., Litman, T., Walker, S. \& Parmenter, R., The GPI Transportation Accounts: Sustainable Transportation in Nova Scotia. Measuring Sustainable Development - Application of the Genuine Progress Index to Nova Scotia, GPI Atlantic, 2006.

[59] Taylor, N., The Urban Transport Benchmarking Initiative Year three final report, European Commission Directorate General for Energy and Transport, 2006.

[60] Appleton, B., Davies, M., Tansey, J., Atwal, P., Dore, G.P. \& Muzyka, D., SMART Transportation Ranking Report Methodology, GreenApple Canada, 2007.

[61] Sessa, C. et al., Transport sustainability indicators: Existing sustainability indicators, knowledge gaps and roadmap towards better indicators and tools, REFIT project - Refinement and test of sustainability indicators and tools with regard to European Transport policies, 2007.

[62] Häkkinen, T., (ed.), Trends and Indicators for Monitoring the EU Thematic Strategy on Sustainable Development of Urban Environment - Final report, Summary and Recommendations, VTT Publications: Espoo, 2007.

[63] Pai, M., Transport in cities - India indicators, EMBARQ, Centre for Sustainable Transport India, 2007.

[64] Maoh, H. \& Kanaroglou, P., Patterns of land use development and sustainable transportation: A simulation approach, 2008.

[65] Maoh, H. \& Kanaroglou, P., A tool for evaluating urban sustainability via integrated transportation and land use simulation models. Environnement Urbain/ Urban Environment, 3, pp. 28-46, 2009.

[66] Costa, M.S., An index of sustainable urban mobility, $\mathrm{PhD}$ thesis, Escola de Engenharia de Sao Carlos, Universidade de Sao Paulo, Sao Carlos, 2008. 
[67] da Silva, A.N.R., Costa, M.S. \& Ramos, R.A.R., Development and application of I_SUM - An index of sustainable urban mobility. Transportation Research Board Annual Meeting, 2010.

[68] Campos, V.B.G., Ramos, R.A.R. \& Correia, D.M.S., Multi-criteria analysis procedure for sustainable mobility evaluation in urban areas. Journal of Advanced Transportation, 43(4), pp. 371-390, 2008.

[69] Litman, T.A., A Recommended Research Program for Developing Sustainable Transportation Indicators and Data, Sustainable Transportation Indicators Subcommittee of the Transportation Research Board, 2008.

[70] Ramani, T., Zietsman, J., Eisele, W., Rosa, D., Spillane, D. \& Bochner, B., Developing sustainable transportation performance measures for TXDOT'S strategic plan: Technical report, Report 0-5541-1, Texas Transportation Institute, The Texas A\&M University System, 2009.

[71] Yigitcanlar, T. \& Dur, F., Developing a Sustainability Assessment Model: The Sustainable Infrastructure, Land-Use, Environment and Transport Model. Sustainability, 2, pp. 321-340, 2010.

[72] Castillo, H. \& Pitfield, D.E., ELASTIC - A methodological framework for identifying and selecting sustainable transport indicators. Transportation Research Part D, 15, pp. 179-188, 2010.

[73] Moussiopoulos, N., Achillas, C., Vlachokostas, C., Spyridi, D. \& Nikolaou, K., Environmental, social and economic information management for the evaluation of sustainability in urban areas: A system of indicators for Thessaloniki, Greece. Cities, 27, pp. 377-384, 2010.

[74] Jeon, C.M., Amekudzi, A.A. \& Guensler, R.L., Evaluating Plan Alternatives for Transportation System Sustainability: Atlanta Metropolitan Region. International Journal of Sustainable Transportation, 4(4), pp. 227-247, 2010.

[75] Jeon, C.M., Amekudzi, A.A. \& Guensler, R.L., Sustainability assessment at the transportation planning level: Performance measures and indexes. Transport Policy, 25, pp. 10-21, 2013.

[76] Gunyoung, K. \& Sangyong, H., Comparative analysis of Transportation sustainability in OECD countries. Journal of the Eastern Asia Society for Transportation Studies, 9, pp. 82-97, 2011.

[77] Zito, P. \& Salvo, G., Toward an urban transport sustainability index: a European comparison. European Transport Research Review, 3, pp. 179-195, 2011.

[78] Awasthi, A. \& Chauhan, S.S., Using AHP and Dempster-Shafer theory for evaluating sustainable transport solutions. Environmental Modelling \& Software, 26, pp. 787796, 2011.

[79] United Nations Centre for Regional Development \& CAI-Asia, Data and indicators for environmentally sustainable transport under the Bangkok 2020 declaration. Sixth regional environmentally sustainable transport forum, 2011.

[80] Litman, T.A., Developing indicators for comprehensive and sustainable transport planning, Victoria Transport Policy Institute, 2011.

[81] United States Environmental Protection Agency (USEPA), Guide to sustainable transportation performance measures, EPA 231-K-10-004, 2011.

[82] Haghshenas, H., Vaziri, M. \& Gholamialam, A., Evaluation of sustainable policy in urban transportation using system dynamics and world cities data: A case study in Isfahan. Cities, 45, pp. 104-115, 2015. 
[83] Nenseth, V., Christiansen, P. \& Hald, M., Indicators for sustainable urban mobility Norwegian relationships and comparisons, Institute of Transport Economics, TØI Report 1210/2012, Oslo, 2012.

[84] Shiau, T.A. \& Liu, J.S., Developing an indicator system for local governments to evaluate transport sustainability strategies. Ecological Indicators, 34, pp. 361-371, 2013.

[85] EcoMobility SHIFT, EcoMobility SHIFT - Assessment and Audit Scheme, Indicators description, EcoMobility SHIFT project, 2013.

[86] Van Rooijen, T. \& Nesterova, N., Applied framework for evaluation in CIVITAS PLUS II, CIVITAS WIKI - Coordination, evaluation and dissemination of CIVITAS PLUS II, 2013.

[87] Santos, A.S. \& Ribeiro, S.K., The use of sustainability indicators in urban passenger transport during the decision-making process: the case of Rio de Janeiro, Brazil. Current Opinion in Environmental Sustainability, 5, pp. 251-260, 2013.

[88] Litman, T.A., Well Measured - Developing Indicators for Sustainable and Livable Transport Planning, Victoria Transport Policy Institute, 2013.

[89] Reisi, M., Aye, L., Rajabifard, A. \& Ngo, T., Transport sustainability index: Melbourne case study. Ecological Indicators, 43, pp. 288-296, 2014.

[90] Mameli, F. \& Marletto, G., Can National Survey Data be Used to Select a Core Set of Sustainability Indicators for Monitoring Urban Mobility Policies? International Journal of Sustainable Transportation, 8(5), pp. 336-359, 2014.

[91] Pitsiava-Latinopoulou, M., Urban mobility and city patterns. In E. Andrikopoulou, A. Giannakou, G. Kafkalas \& M. Pitsiava-Latinopoulou, City and Urban Planning Practices towards Sustainable Development $-2^{\text {nd }}$ revised edition, Kritiki Publications: Athens, 2014.

[92] Moeinaddini, M., Asadi-Shekari, Z. \& Shah, M.Z., An urban mobility index for evaluating and reducing private motorized trips. Measurement, 63, pp. 30-40, 2015.

[93] Alonso, A., Monzon, A. \& Cascajo, R., Comparative analysis of passenger transport sustainability in European cities. Ecological Indicators, 48, pp. 578-592, 2015.

[94] Shiau, T.A., Huang, M.W. \& Lin, W.Y., Developing an Indicator System for Measuring Taiwan's Transport Sustainability. International Journal of Sustainable Transportation, 9(2), pp. 81-92, 2015.

[95] Verma, A., Rahul, T.M. \& Dixit, M., Sustainability impact assessment of transportation policies - A case study for Bangalore city. Case Studies on Transport Policy, 3, pp. 321-330, 2015. 